\title{
Ethics in Practice: Conversations about Biobanks
}

\author{
Anne Scott, Hazel Phillips, Andrew Moore, Rosemary Du \\ Plessis \\ Submitted to Critical Public Health \\ 2004
}

Anne Scott and Rosemary Du Plessis

School of Sociology and Anthropology

University of Canterbury

Hazel Phillips

Iwi - Ngāti Mutunga

Māori Research \& Development

Christchurch Polytechnic Institute of Technology

Corresponding Author:

Andrew Moore

Department of Philosophy

University of Otago

P.O. Box 56

Dunedin, New Zealand

Fax: 006434795035

Email: Andrew.Moore@stonebow.otago.ac.nz 


\title{
Ethics in practice: Conversations about Biobanks
}

Anne Scott, Hazel Phillips, Andrew Moore, Rosemary Du Plessis

\begin{abstract}
This paper uses the concept of 'ethicality' to analyse focus group conversations in New Zealand about biobanking and genetic testing. 'Ethicality' has been used by Arohia Durie, a Māori educationist, to highlight how ethical talk and practice is historically and socially positioned, situated within specific life-worlds, embedded within always partial communities, and articulated within individual life narratives. This situated ethicality is identified in the talk of Māori and non-Māori research participants. The authors (a moral philosopher, two sociologists and a kaupapa Māori social researcher) argue that serious consideration of ethicality presents significant challenges to the abstracted character of much expert ethical analysis, while also illustrating connections between 'ethics talk' and expert discourses.
\end{abstract}

Key words: genetic testing, biobank, bioethics, indigenous, Māori, biotechnology, narrative; ethicality, situated knowledges 


\section{Introduction}

What you were going to discuss tonight was the ethics. Now, are you going to do that next time? (Jacob, focus group participant, religious organisation)

If you're thinking about the actual ethical behaviours and codes to be followed as ethics, then yes, we've barely started. You launched us off on some of that, but we haven't developed it, whereas the real fundamental questions that we have been kicking around are at the heart of ethics. (Ken's response to Jacob)

This paper examines the 'fundamental questions' focus group members 'kicked around' in discussions about biobanks and genetic testing in Aotearoa New Zealand in 2003 and 2004. These focus groups were part of a research project directed at greater public participation in decision-making about new health biotechnologies. ${ }^{1}$ At one of these meetings, Jacob, a retired engineer, offered a comprehensive account of the issues he considered important. His concerns mirrored some of the issues discussed in recent ethical literature relating to biobanks, ${ }^{2}$ but were not taken up by others in the group. However, their conversation was suffused with references to morality, values and spirituality. Talk about moral issues was situated and particular, expressed through personal examples and storytelling. Had this discussion gone to the heart of ethics, or had the ethical discussion 'barely started'? The answer hinges on what ethics is, both as an expert discourse and as everyday practice.

We argue that critical analysis of biobanks and genetic testing requires not only the input of expert ethicists, but also attention to 'ethicality' - the situated, specific and experiential ethics talk of other citizens. Ethicality is a term coined by Arohia Durie (1998: 261) to identify a specifically Māori critique of expert ethics that at the same time recognises the 'values, beliefs, attitudes and knowledges' that people generally bring to their ethical talk and practice. Ethicality is embedded in the complex and messy business of living within socially and historically constituted life-worlds and means of understanding reality (Haraway 1997: 273).

Embeddedness within always partial communities is present to some degree in all ethical thinking, but ethicality sits at one end of a continuum. At the other end of this continuum are more abstract and generalising expert discourses of ethics. These discourses exhibit what Zygmunt Bauman (1993: 194) has referred to as 'close focusing' in which a problem is 'cut out from the tangle of its multiple connections with other realities, while the realities to which it is connected are left out of account and melt into the indifferent "backdrop" of action'.

The tendency to abstraction that characterises many expert ethical discourses is illustrated by particular theories about ethical action. According to Scanlon (1998:5) 'the rightness of an action is determined by whether it would be allowed by principles that no one could reasonably reject', while Hursthouse (1999:28) has argued that 'an action is right [if and only if] it is what a virtuous agent would characteristically (i.e., acting in character) do in the circumstances'. Hooker (2000:32) has stated, with similar generality, that 'an act is wrong if and only if it is forbidden by the code of rules whose internalization by the overwhelming majority of everyone everywhere in each new generation has maximum expected value'. Less ambitious forms of ethical and bioethical theory that attend to the challenges of particular contexts are 'cut out' of these accounts.

Rawls (1980) offers a more contextualised approach to ethics. He argues that the ethical beliefs we express in particular settings, and the general commitments or principles we endorse, both have some standing and all our ethical thought is better justified to the extent that they are brought together in a coherent 'reflective equilibrium'. Others have argued that the theoretical principles of expert ethics are 'crystallisations of the insights that emerge out of a people's ongoing experience' (Morris 2002: 199). This paper attempts to contribute to a contextual, embedded and experiential approach to the ethics of biobanks through an exploration of the complex and politically situated talk of participants in community-based focus groups. 
After a description of the research strategy used to generate the conversations analysed in this paper, we discuss the ethical understandings articulated in focus groups that primarily involved Pākeha participants (New Zealanders of European descent). We suggest that their ethical talk is embedded in personal narratives and their social positioning. In the next section, we analyse discussions in focus groups composed specifically of those involved in Māori (indigenous peoples of Aotearoa New Zealand) community networks and highlight the ways in which their response to biobanking and genetic testing are embedded with Māori conceptual frameworks and specific historical interactions between Māori and non Māori. Finally, we return to the significance and inevitability of situated ethical understandings of biobanking, and the need to develop ethical thinking with due regard for partial or multiple forms of citizenship.

\section{Research strategy}

Twenty-five focus groups that discussed genetic profiling, direct-to-consumer genetic testing and biobanking were conducted in eight different locations by twelve researchers in 2003 and 2004. As part of a 'parallel process' facilitating culturally appropriate spaces for Māori participants' discussions (Cram, et al 2004), nine of the focus groups consisted solely of Māori participants, usually facilitated by Māori research team members. The other sixteen focus groups were drawn from community groups and informal networks that were not Māori specific. Participants in these groups were mainly Pākeha, but also included some Māori and people of other ethnicities. ${ }^{3}$

Focus groups were mainly recruited from people in existing community and social networks. They encompassed community groups, religious organisations, professional and business organisations, workplace based groups, scientists, adult education groups for older and younger adults, health support groups, health providers and friendship/ kinship groups. Māori health providers, health support groups, adult education groups, religious groups, family/whānau groups, professionals and iwi/tribal organisations were included. In most focus group meetings, participants already knew some of the other participants. When participants did not know one another, they were usually involved in related areas of work or community activity.

The groups were facilitated by researchers in various settings in both the North and South Islands. Researchers utilised their location in a variety of different networks and as well as letters, phone calls and advertisements in newsletters to contact participants. Conversations were recorded and transcribed verbatim. Three sets of materials were used to facilitate talk about biobanking and genetic testing. These materials included a hypothetical story about genetic profiling, a fictional advertisement for direct-to-consumer genetic testing, and a mock pamphlet that provided information about a newly established biobank.

After facilitating these groups, the authors of this paper (a moral philosopher, two sociologists, and a kaupapa Māori social researcher) reflected on how the ethical talk or ethicality of research participants was embedded in particular social worlds and collective and personal narratives. We embarked on a close reading of the transcripts that focused on the use of normative language, references to values, cultural and spiritual beliefs; as well as the use of values-orientated narratives, personal and collective. This paper presents examples of their situated ethical talk.

The analysis of ethicality in the Māori specific groups and in those drawn from other groups and organisations (which sometimes included Māori participants) is presented separately. This is consistent with a decision made by the research team that Māori researchers would be the first analysts of the transcripts of Māori specific focus groups. This was informed by the principles of kaupapa Māori research to which key team members were committed. These principles include doing research in ways that are consistent with Māori values and customs, but also ensure Māori control over the knowledge that is produced through research that involves Māori participants (Smith, 1999; Cram, 2001).

Kaupapa Māori research entails a critical approach to western theoretical and analytic frameworks and a commitment to using Māori conceptual tools to understand and explain Māori experiences. For this reason, two parallel, but closely related analyses are 
offered below. The first uses the concept of situated ethicality to analyse the ethics talk of predominantly Pākeha participants. The second analysis draws on Māori conceptual tools to discuss conversations about the ethicality of genetic testing and biobanking in Māori specific focus groups.

\section{Situated Ethicality}

The quality of ethicality was unevenly distributed through the sixteen focus group conversations that involved predominantly Pākeha participants. These variations were related to age and social positioning; ethically oriented talk was less evident amongst groups drawn from professional and business organisations, and groups of younger people. Amongst groups with religious affiliations, groups of older people, and groups constituted from socially marginal locations (e.g., community cottages, health support groups, etc), personal story-telling was more likely to be integrated with complex and multi-faceted consideration of ethical norms in relation to biobanking and genetic testing.

While attitudes towards genetic testing and biobanking varied somewhat, two key themes were identified. One of these themes relates to understandings about 'the good society', and includes broad concerns relating to self-determination, ${ }^{4}$ the development and maintenance of community, and trust in those developing these biotechnologies and regulating their use. The second theme relates to the importance of each life journey; it includes concerns about eugenics and 'playing God'.

For these predominantly Pākeha participants, self-determination was significant and involved choice at both and individual and a collective level. However, 'choice' with respect to decisions about genetic testing and the storage of genetic information was also seen as complex and difficult to ensure. Participants worried about people's ignorance of the possible dangers of providing samples of their DNA. They were concerned about financial pressures that might be brought to bear, new social expectations about having 'the right genes', and the potential development of a eugenic mentality that prioritised the elimination of disability and inherited genetic illness. Participants in a number of focus groups considered these complexities regarding informed choice by telling stories about people making difficult choices in relation to health care (Morris 2002).

Self-determination also emerged as an important issue at the collective level, but many participants in our research felt powerless to influence the pace or direction of technological change: We end up as a society being tossed by decisions that are made without the ethical and value discussion occurring before they are made. (Joshua, member of a religious organisation)

The theme of self-determination is also prominent in the published literature on ethical issues concerning biobanks established for research purposes. Much of this work aims to specify acceptable consent processes to facilitate broad future research use of biobanked tissue, but rejects, as an unacceptable loss of self-determination for those whose tissue is banked, the idea of blanket consent to future unspecified research uses (National Bioethics Advisory Committee 1999; Clayton, Steinberg, \& Khoury 1995). A further major sub-theme in the published literature concerns participant determination of the flow of information regarding their banked tissue (Anderlik \& Rothstein 2001).

Some participants were uneasy about the involvement of commercial companies in biobank and genetic testing initiatives. Some of this disquiet related to the diversion of public health resources into genetically based research and therapeutics, which was seen as undermining community resources for private benefit. A desire for profit was often described as incompatible with the development and sustaining of community.

Discomfort with treating human tissue as property, and as straightforwardly subject to commercial transaction, is also widely expressed in the published literature and international statements on biobanks, and in the self-presentation of biobank sponsors. The biobank Ardais, for example, presented itself in its online 2001 'What people ask (Q and A)' as collecting human tissue otherwise destined for disposal, and as doing so for purposes of generating valuable clinical materials and associated information in exchange for licence fees. It did not present itself as a buyer or seller of tissues or of products and services derived 
from tissues (Anderlik 2003). Commercial entities are prominent in many countries in the development of biobanks, though there has also been some exploration of the possibilities of 'tissue trustee' organisations (Winickoff and Winickoff 2003; Otten et al 2004).

In almost two thirds of the general focus groups there was a significant lack of trust in those developing new biotechnologies. A strong sense of 'them' and 'us' emerged in many of these accounts; the pain of being 'othered', of being enrolled into techno-social conventions not of one's own making (Star 1991), was evident. Commercial organisations such as pharmaceutical companies or insurance brokers were often constructed as 'them'; as also in a number of cases were employers, government, scientists or the medical profession.

Use of narrative enabled participants to hold in view ambiguity and complexity, attending both to individual integrity and to the structural forces that might lead to unpredictable outcomes.

One thing that worries me is the ethics. Now nobody will convince me that the medical profession is so absolute in their integrity that opportunities to do things - in the long-term future we don't know what might happen... the Hippocratic Oath doesn't mean much at all when different pressures are applied to these people, and that, I think, is one of the worries for the longterm future. (Ray, member of an adult education group (older adults))

'Ethicality', as we are describing it, cannot be fully understood in isolation from history, or from socio-political power. It is partial, and is diffracted through historical memory and cultural location. This included historically specific scepticism about whether you could trust governments to maintain and enforce regulatory regimes and ethical protocols with respect to genetic data.

I think it is a political issue again. And it is a matter of trust. So, my feeling is that it's a good thing, but knowing how things can change, you know the political... the whole thing can just change overnight, basically. Just in this, I don't know that one could trust. It's not a matter of not trusting the scientists. It's a matter of not trusting the political environment. (Caterina, mid career adult friendship group) ${ }^{5}$

For Caterina, and others in her focus group, ethicality was deeply embedded in valuations relating to trust and the quality of relationships; an experience of political betrayal in one political context has undermined trust in a quite different political context. The relationship between citizens and the 1984 New Zealand Labour government is the thread linking these experiences.

The lack of trust felt by participants was associated with expressions of fear that genomics might lead to governments, employers, insurance brokers, or others, attempting to 'play God', to control the type of people within society, or the direction of personal and social change. Such actions were seen as ethically wrong, not simply because they might lead to genetic discrimination, to eugenic abortions, or to less democratic societies, but also because they undermined the capacity of each individual to pursue his or her life trajectory. This was explicitly valued in almost every focus group. Research participants often moved from specific stories and experiences to more general or abstract conclusions about policy, illustrating perhaps a Rawlian 'reflective equilibrium' (Rawls 1971, Arras 1997: 70-71). In this respect, the stories and images related to ethics talk '... are those that depict good lives and bad lives, human flourishing and its contrary' (Murray 1997: 14).

Within the sixteen predominantly Pākeha focus groups attention to the value of each individual life and personal choice was combined with a concern about constructing or preserving the 'good society'. Discussion of issues such as genetic discrimination, privacy of genetic information, and confidentiality, occurred in the context of this broader 'ethicality'.

I've got no particular, no ethical problem, with taking a blood sample... it's not a particularly intrusive process. And providing privacy can be assured...I probably don't have a great problem with it... I mean, there are a lot of mechanisms already for ensuring privacy of information to your doctor and that 
sort of thing. But I guess I do worry about the ethics of having - it's a bit like knowing when you're going to die. That would make quite a difference to your life, wouldn't it? (Daniel, member of adult education group 1 (older adults))

Most of the current literature on biobanks explores the rights of particular individuals whose tissue is banked, rather than broad issues such as 'trust' or conceptions of 'the good society'. The focus is on individual rather than collective self-determination.

In the next section, we explore ethics talk in the nine Māori specific focus groups. The themes that emerge are similar to those explored above, however, Māori specific conversations also highlight significant areas of difference in the way Māori and non-Māori participants in this study responded to the same research material.

\section{Whakapapa, tikanga and mana motuhake: a lived ethicality}

Despite their diverse social and cultural locations, ${ }^{6}$ Māori responses to issues about genetic testing and the storage of genetic material exhibited an ethicality grounded in traditional Māori values and practices, as well as the contemporary realities of being Māori. Reflections on their own lived realities and those of their iwi, hapu and whānau (tribe, sub-tribe and family) informed their discussions of biotechnologies and biobanking. Like the primarily Pākeha participants discussed above, Māori participants' narratives exhibited a critical awareness of their situatedness. These participants' narratives were deeply rooted in traditional knowledge, values and practices, as well as the historical experience of colonisation in which their tipuna (ancestors) became a subjugated people - linguistically, culturally, socially, and politically - in their own land. However, while these narratives expressed awareness of historical oppression, they were also optimistic and forward-looking. Mārama's narrative illustrates this positioned ethicality.

We've got our own academics with our own tikanga [protocols and practices], but not in the way of the western world, so I'm very suspicious of biobanks to start with. Who has the intellectual right to do this, who owns this and why should it be owned? Nobody owns genes, it's not a matter of owning genes, we wear our own tino rangatiratanga [self-determination]. It's about understanding disorders, it's not about the cure of disorders. We don't know what the outcomes are from genetic engineering or from having a biobank. And from a biobank comes maybe ... I'm sure it would happen, the misuse of information. It would be misused into changing whakapapa [genealogy], and we have no power over that. You know I want my mokopuna [grandchildren] to know their whakapapa.... (Mārama, rongoa group) ${ }^{7}$

Embedded in Mārama's critique is a Māori specific positioned ethicality. Like many of the participants in the Māori specific focus groups, her discursive ethicality draws on the concepts of whakapapa, tikanga and mana motuhake to think about biobanking and genetic testing. Whilst the underlying meanings of these concepts are not exclusive to Māori, they are embedded in and resonate with Māori understandings of the world.

It is through whakapapa, the tracing of one's maternal and paternal ancestors that the Māori world is and is known. Essentially about relationships - past, present and future - whakapapa connects people to the spiritual world and the physical landscape, to everyone and everything in the universe. Whakapapa is expressed through genealogical connections between people, and this shapes the way Māori see themselves and relate to one another. The practice of kinship obligations and responsibilities give form and substance to whakapapa. Mārama was one of many participants expressing a situated and relational ethicality. This is articulated in her concern about the ways in which biobanking has the potential to desecrate whakapapa and, by implication, the essence of being Māori. 
To fulfil obligations and responsibilities and look after people with respect and care means to act in ways that are right or proper. Of crucial importance for Māori are relationships that are tika - true, just, upright and honest (Jenkins 2000). This shapes Māori customary practices, otherwise known as Māori law or tikanga and regulates the relationships Māori have in the world, whether this involves settling disputes, collecting seafood or participating in research. Tikanga, or courses of action to establish and maintain tika relationships, remains an abiding concern for Māori (Marsden and Henare 1992). In this way ethical practice involves 'walking the talk', where actions speak louder than words. Tikanga is wholly about an ethicality of practice (Durie, A., 1998) and draws its meaning from practice as much as it does from discourse.

At the core of tikanga is the notion of mana, which can only be understood through relationships (Mead 2003). Whilst mana has a range of meanings (Williams 1992), the meaning that is relevant here is the integrity of a person or group that is manifest in action (Hohepa 1998, Marsden 1998). In the Māori world, virtually every activity or ceremony is linked with the maintenance and enhancement of mana (Marsden 1998). While it is both inherited and bestowed, it is not something that people, or groups, can claim for themselves. It is only in collective contexts that mana is established. To ensure that mana is preserved and enhanced, people need to act generously and respectfully towards each other.

Mana motuhake extends the concept of mana. While it is understood as selfdetermining authority, it is more than that, as it asserts the legitimacy and validity of being Māori. A political struggle for self-determination is embedded in the participants' narratives, including Mārama's. ${ }^{8}$ Many of the participants specifically referred to the Treaty of Waitangi ${ }^{9}$ as the vehicle for mana motuhake. Signed in 1840, the Treaty of Waitangi signalled the negotiated settlement of Aotearoa/New Zealand, in which both Māori and settler were accorded both universal and separate rights. In particular, Māori were guaranteed continued authority over their own estates and 'taonga' - all aspects of Māori society that were valued. Seen as the blueprint of the nation (despite its lack of legal status) Māori invoke the Treaty as leverage in their calls for justice and selfdetermination. Māori participants argue that, as Treaty partners, Māori should have control over their genes and ultimately their future, including future generations.

... we have to have control over it [biobanking] and I think that's where the

Treaty partnership really comes into play in terms of that protection afforded to Māori under the Act. ... Māori need to be actively participating at the decision-making level, because that's how it should be. (Anahera, Māori lawyers group)

Both Anahera's and Marama's narratives allude to the impact of colonial practices that have continued to marginalise Māori. Many participants' talk highlighted the way in which Māori brought their historical and contemporary experiences of being 'other' to their critical understandings of science and debates about biobanks, genetic testing and biotechnologies.

Ethicality is always diffracted through particular communities. It will, of necessity, lead to understandings which are historically specific and suffused with memories of other, quite different, historical experiences. The challenge for ethicists is to bring to discussions about biobanking and other new technologies a sensitivity to these experiences, and the diversity of ethical concerns associated with them. Indeed, many of the Māori participants argued that those involved must consider the interests and worldviews of the communities they work and live in.

\section{Conclusion}

'Ethicality' is ethical thinking that is located in specific life experiences. It is suffused with historical awareness and collective memories, which often range far from the seeming topic of consideration and, as the concept of 'mana' illustrates, ethicality is as much about integrity of practice as it about defensible reasons for action. The theories of a number of expert ethicists ${ }^{10}$ specify the conditions under which any action is right at any time. 
Ethical theory can be strikingly ambitious. Equally striking, however, is the narrowness of the range of the reflective judgments and the ethicality to which the ethical theorists typically appeal. In a few cases (e.g., Hare 1981, Brandt 1979, Singer 1974), this is because they argue that citizens' reflective ethical judgments - including their own - have no justificatory weight. Ethical theorists in the Rawlsian mainstream, however, are committed to the view that citizens' reflective ethical convictions do have some standing, and do bear on the formulation and justification of ethical theories. This being so, the range of citizens whose ethical judgements these theorists actually examine is very much narrower than the class of all citizens, in all cultures, times, and places, both actual and possible. Rawls and his many followers frequently appeal to 'our' considered convictions (e.g., Rawls 1980: 534), but the scope of this 'our' is under-examined, with little or no argument or evidence being offered that it invokes a substantial population.

This paper has presented some of the richness and range of the ethicality of a small number of Māori and Pākeha citizen groups in one small country and in one set of conversations about biobanks and genetic testing. Their talk about ethical problems, such as the ownership of genetic data generated from study of biobanked tissue, was usually embedded in 'the tangle of its multiple connections with other realities' (Bauman 1993:194). It was embedded in their socially and historically positioned life-worlds, and their understandings of community, identity and citizenship.

It is the ethical understandings that emerge out of thoughtful engagement with experience that underpin attempts to express ethical thought in terms of principles, virtuous character states, criteria for ethically right action and rules for the formation of policy. Both the feasibility and the desirability of such projects of abstraction and generalisation are contentious. If they are to be pursued at all, this should encompass engagement with particular, situated ethicalities of the sort that this paper has explored.

The situated ethicalities reviewed in this paper were organised around a keen understanding of the meanings of 'citizenship' in a diverse, secular society with a colonial history and a Eurocentric tradition. For Māori participants in particular, discussion of biobanking and genetic testing could not be separated from the specifics of history and of contemporary struggles over physical and cultural resources as well as the applications of scientific knowledge. Yet conversations among both Māori and Pākeha participants did not separate 'ethics' from questions of community, trust and self-determination. Collective concerns were often the basis for assertions about what should happen, and about the moral responsibilities of individuals, whanau, hapu and iwi, local communities, professional groups and the state. Regardless of their ethnicity, participants were concerned about the moral impacts of developments in human genomics and the storage of genetic information. Their embedded ethicality was articulated at a particular time in Aotearoa New Zealand, but components of their ethical talk are potentially also relevant in other contexts and among those of different ethnicities. 


\section{References}

Anderlik, M. (2003) 'Commercial Biobanks and Genetic Research', American Journal of Pharmacogenomics 3 (3): 203-215.

Anderlik, M.; Rothstein, M. (2001) 'Privacy and Confidentiality of Genetic Information: What Rules for the New Science?' Annual Review of Genomics and Human Genetics (2): 401-33.

Arras, J. (1997) 'Nice story but so what: narrative and justification in ethics', in Nelson, H.L. (Ed), Stories and their Limits: Narrative Approaches to Ethics. London: Routledge.

Bauman, Z. (1993) Postmodern Ethics. Blackwell, Oxford.

Brandt, R. (1979) A Theory of the Good and the Right. Oxford: Oxford University Press.

Clayton E.; Steinberg K.; Khoury M. (1995) 'Informed consent for genetic research on stored tissue samples', Journal of the American Medical Association; 274: 17861792.

Cram (2001) 'Rangahau Māori: Tona tika, tona pono- The validity and integrity of Māori research', in Tollich, M. (ed.) Research Ethics in Aotearoa, Auckland: Longman, an imprint of Pearson Educational.

Cram F. et al (2004) 'A 'Parallel Process'? Beginning a constructive conversation about a Māori Methodology’. Journal of Bioethical Inquiry. 1(1): 14-19.

Durie, A. (1998) Me tipu ake te pono: Māori research, ethicality and development. Te Oru Rangahau: Māori Research and Development Conference, Massey University, Palmerston North.

Durie, M. (1998) Te Mana, Te Kawanatanga: the politics of Māori self-determination. Oxford University Press, Auckland.

Easton, B. (1997) The commercialisation of New Zealand. Auckland: Auckland University Press.

Haraway, D. (1991) 'Situated knowledges: the science question in feminism and the privilege of partial perspective', in Simians, Cyborgs and Women: The Reinvention of Nature. London: Free Association Books.

Haraway, D. (1997) Modest_Witness@Second_Millennium.

FemaleMan C_Meets_OncoMouse ${ }^{\mathrm{TM}} \cdot \overline{\text { Feminism }}$ and Technoscience. New York: Routledge.

Hare, R. (1981) Moral Thinking. Oxford: Oxford University Press.

Hipkins, R. (2004) 'Methodological Overview - Phase 1' Working Paper 1, Constructive Conversations / Kōrero Whakaetanga http://www.conversations.canterbury.ac.nz

Hohepa, P. (1998) 'The taking into account of Te ao Māori in relation to reform of the law of succession'. In the Mental Health Foundation, Te Aro Rangahau: Contemporary Māori Mental Health Issues. Mental Health Foundation, Wellington.

Hooker, B. (2000) Ideal Code, Real World: A Rule-consequentialist Theory of Morality. Oxford: Clarendon Press.

Hursthouse, R. (1999) On Virtue Ethics. Oxford: Oxford University Press.

James, C. (1992) New territory: the transformation of New Zealand, 1984-1992. Wellington: Bridget Williams Books.

Scanlon, T. (1998) What We Owe to Each Other. Cambridge, Mass. and London: Harvard University Press.

Singer, P. (1974) 'Sidgwick and reflective equilibrium', Monist 58, 490-517.

Smith, L. (1999) Decolonizing Methodologies: research and indigenous peoples. Zed Books, London, and University of Otago Press, Dunedin.

Vowles, J.; Aimer, P. (1993) Voter's Vengeance: the 1990 election in New Zealand and the fate of the fourth Labour government. Auckland: Auckland University Press.

Walker, R. (1989) 'The Treaty of Waitangi: as the focus of Māori protest'. In I. H. Kawharu (ed.), Waitangi: Māori and Pākeha perspectives of the Treaty of Waitangi. Oxford University Press, Auckland. 
Ward, A. (1999) An unsettled history: Treaty claims in New Zealand today. Bridget Williams Books, Wellington.

Williams, H. (1992) A dictionary of the Māori language. Wellington: GP Publications. ( $7^{\text {th }}$ edition revised and augmented by the Advisory Committee on the Teaching of Māori Language, Department of Education. $1^{\text {st }}$ edition published 1844)

Winickoff, D.; Winickoff, R. (2003) 'The Charitable Trust as a Model for Genomic Biobanks', New England Journal of Medicine, 349(12), September 18, 2003: 1180-1184.

\section{Endnotes}

${ }^{1}$ Constructive Conversations/Kōrero Whakaaetanga, is a five year research project funded by the New Zealand Foundation for Research, Science and Technology (FRST). The 14 member, multi-sited research team is led by Rosemary Du Plessis, of the University of Canterbury and Bevan Tipene-Matua, Christchurch Polytechnic Institute of Technology.

${ }^{2}$ See the recent survey by Anderlik (2003) that focuses especially on commercial biobanks and genetic research.

${ }^{3}$ See Hipkins (2004), 'Methodological Overview - Phase 1', available on the Constructive Conversations/Körero Whakaaetanga website: http://www.conversations.canterbury.ac.nz .

4 'Self-determination' is a concept with multiple and contested meanings. Māori, and other indigenous peoples, often use it to reflect aspects of their struggles against marginalisation and dispossession; this is one of its most important meanings in Aotearoa/ New Zealand. We use it in relation to Pākeha talk to highlight the fact that, although this talk of freedom and 'choice' is often individually focused, it also includes elements of a collective struggle for community control, inclusion and democracy.

${ }^{5}$ Caterina is referring to the neo-liberal reforms instituted by New Zealand's fourth Labour government during the 1980s. A government elected on a social democratic platform cut state subsidies for industry and farming. This was combined with the commercialisation of state owned enterprises and the eventual sale to private companies of utilities such as telecommunications and rail. See Easton (1997), James (1992), Kelsey (1995), Vowles and Aimer (1993).

${ }^{6}$ These included iwi (tribal) groups and cross iwi networks; health support groups; Māori professionals and members of an international religious organisation; those 
immersed in and dedicated to preserving Māori traditional culture and those with tenuous links to Māori knowledge and custom.

7 'Rongoa' means to preserve, to take care of, and is associated with medicine and medicinal practice. The participants of the rongoa focus group are members of a traditional Māori health service.

${ }^{8}$ Another phrase for self determination is tino rangatiratanga, which is used by Mārama.

${ }^{9}$ The Treaty of Waitangi consists of a preamble and four articles (the fourth being verbally agreed to on the day). For an overview of issues relating to the Treaty of Waitangi see Durie, M. (1998), Walker (1989), and Ward (1999).

${ }^{10}$ See review of the positions of normative ethicists such as Scanlon (1998), Hursthouse (1999) and Hooker (2000) in the introduction to this paper. 